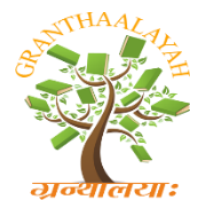

INTERNATIONAL JOURNAL OF RESEARCH GRANTHAALAYAH

A knowledge Repository

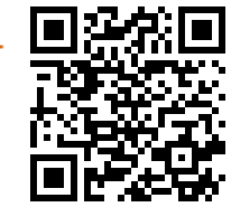

Social

\title{
ORGANIC FARMING PRACTICES IN SIKKIM SCHOOLS: A PATH TO EDUCATION FOR SUSTAINABLE DEVELOPMENT
}

\author{
Genevive Syangbo *1 \\ ${ }^{* 1}$ State Council of Educational Research and Training (SCERT), Gangtok - Sikkim, India
}

\begin{abstract}
The National Curriculum Framework 2005 under its guiding principles includes the need to make 'children sensitive to the environment and the need for its protection' while living in harmony within oneself and with one's natural and social environment as an important curricular concern (p6). Education for Sustainable Development (ESD) with its emphasis on fostering of 'competencies that enable students to find sustainable solutions to demanding issues and prevent conflicts' in their world is seen as a process towards such a goal. In this regard, Sikkim's initiative towards achieving this broader aim of education has been an ongoing process in schools of Sikkim. This paper presents, from an educational perspective, integration of Education for Sustainable Development (ESD) through practice of Organic farming in government schools in Sikkim. This enables the objective of embedding ESD goals aiming towards development of competencies among learners for sustainable living.

The paper also focuses on how the concept of organic farming and green schools has been incorporated into the school curriculum. The process involving schools and the community to work together through a participatory and collaborative approach is enabling all stakeholders of school education to understand and practice the principles of sustainable development with available resources within their communities.
\end{abstract}

Keywords: Sikkim; Schools; Integration; Organic; Farming; Sustainable Development.

Cite This Article: Genevive Syangbo. (2019). "ORGANIC FARMING PRACTICES IN SIKKIM SCHOOLS: A PATH TO EDUCATION FOR SUSTAINABLE DEVELOPMENT." International Journal of Research - Granthaalayah, 7 (5), 128-136. 10.29121/granthaalayah.v7.i5.2019.831.

\section{Introduction}

'To reorient a curriculum to address sustainability, educational communities need to identify the knowledge, issues, perspectives, skills, and values central to sustainable development in each of the three components of sustainability - environment, society, and economy - and integrate them into the curriculum' (Education for Sustainable Development, UNESCO, 2017).

In 2005, the United Nations launched "The Decade of Education for Sustainable Development (DESD)" emphasizing on the integration of the principles, values and practices for nurturing 
sustainable development in education (Sharma. K \& Pandya. M, 2015). This effort of the UN about achieving educational sustainability led to imbibing Sustainable Development Goals (SDG) in school curricula which has been equally emphasized and addressed by various education related agencies in India and the world.

The focused discussion here is that the student learning should be directed towards meeting the future challenges of society, environment and economy. Zouari Ahlem and Mohamed Amine Hammas (2014) in their work "Organic Farming: A Path to Sustainable Development" talks about the alignment of Organic farming with sustainable development approach. They argue that learning about Organic agriculture as a factor of sustainable development is fully required for the society, environment and the economy at large. Teaching Organic farming as an element of ESD contributes towards sustainable development which includes learning about not only the farming and food systems but also preparing the children with required capacities needed for responsible future action.

In this regard, the adoption of organic farming in government Schools in Sikkim is in alignment with this objective of ESD. This learning through experiences inside and outside the classrooms for environmental concerns is also in consonance with the principles of UNDESD-2005 and its recommendations.

The heart of this initiative of incorporating organic farming as co-curricular activity in schools of Sikkim is to apply learning ecological principles prioritizing sustainability challenges. It enables working closely with environment, farming and food system stakeholders in designing and implementation of its outputs. The activity of farming contributes to develop important learning skills for autonomous and lifelong learning. Practices from organic farming and other related agricultural farming strategies equips the students to counter with difficult challenges in agro ecology and related practices, including observation, participation, reflection, dialogue, and visioning. These capacities are applied in their life-long learning process which affirms their skills to provide responsible action in a complex and uncertain future.

Institutionalization of Organic farming practices in schools is directly aligned to the basic tenets of ESD enabling self -participation for a sustainable society, fostering competencies and inter connectedness. This initiative undertaken by the Human Resource Development Department, Government of Sikkim also strengthens one of the curricular areas in schools, 'Work and Education', listed in NCF 2005 which emphasizes 'the pedagogic potential of work as a pedagogic medium in knowledge acquisition, developing values and multiple skill-formations' (NCF, 2005). The declaration made by the Government of Sikkim in 2003 that Sikkim would be a fully organic state by the year 2015 and the Sikkim Organic Mission launched on 15th August 2010 set the road of organic farming in the state (RMSA, HRDD Report on Organic Farming in schools, 2018).

Following this, the Human Resource Development Department (HRDD), Govt. of Sikkim in 2017 under Rashtriya Shiksha Abhiyan (RMSA) initiated the adoption of organic farming in Secondary and Senior Secondary Government Schools in Sikkim. The main objective of the programme being the integration of sustainable learning through hands on experiences and life skills development among students. 
With the aim of creating sustainable education, out of a total 767 government schools among the 4 districts, organic farming was initiated in 34 pilot schools that included Secondary and Senior Secondary Government Schools in Sikkim. The schools were provided with farming tools, seeds and organic composting materials. Technical support was led by the Horticulture and Cash Crops Development Department and Food Security \& Agriculture Development Departments. An initial grant of Rs. 7000/- (per school) was provided from HRDD. Various orientations and workshops were also conducted on Organic farming. In October, 2018, the project was extended to 89 more Secondary and Senior secondary schools. Sustainable development through Organic Farming in schools is being extensively carried forward in these pilot schools in Sikkim.

\section{Objective of the Study}

The main objective of the study is to understand the processes of embedment of principles of Education for Sustainable Development in the practices of Organic farming in Government schools of Sikkim. The study also tries to find out the participatory and collaborative approach adopted by the schools in the process of organic farming for enabling sustainable learning and living.

\section{Methods}

The source of the data for this study is primary data acquired through questionnaire, interview and school visits. Of the first 34 schools selected, the survey was conducted to 20 pilot schools where organic farming project was initiated by the Human Resource Development Department, Government of Sikkim. Accordingly, questionnaire was administered to these 20 pilot schools to collect the required data and information for the study.

\section{Results and Discussion}

From the survey study of the 20 pilot schools of organic farming, it was observed that all schools were engaged in various farming activities. The majority of initiatives by schools used internal sources (HRDD) for funding, with all 20 schools drawing external support to develop their initiatives on organic farming. The data collected reveals that all the schools have been producing multiple items and engaging students and teachers directly in the process. The schools use much of their farming products for mid- day meal (MDM) and only nine schools are engaged in marketing the produce.

The following part of the paper gives an insight on the practices of organic farming of selected twenty schools which represents all four districts of the state.

The findings are supported with tables and figures. 
Table 1: Year wise Organic Products in the schools of West district

\begin{tabular}{|c|c|c|c|c|c|c|c|}
\hline $\begin{array}{l}\text { Sl. } \\
\text { No }\end{array}$ & $\begin{array}{c}\text { Name of } \\
\text { School }\end{array}$ & $\begin{array}{c}\text { Area of } \\
\text { Land used } \\
\text { for Farming } \\
\text { (approx in } \\
\text { acres) } \\
\end{array}$ & Year & $\begin{array}{l}\text { Name of the } \\
\text { crops / } \\
\text { Vegetables } \\
\text { grown }\end{array}$ & $\begin{array}{l}\text { Production } \\
\text { (in Kg.) }\end{array}$ & $\begin{array}{c}\text { Produce } \\
\text { used } \\
\text { in MDM } \\
(\%)\end{array}$ & $\begin{array}{l}\text { Produce } \\
\text { Sold }(\%)\end{array}$ \\
\hline \multirow[t]{2}{*}{1} & \multirow[t]{2}{*}{$\begin{array}{l}\text { Kripasalyan- } \\
\text { Daramdin SSS }\end{array}$} & \multirow[t]{2}{*}{1 acre } & 2017 & $\begin{array}{l}\text { Potato } \\
\text { Lady Finger } \\
\text { Radish }\end{array}$ & $\begin{array}{l}300 \\
80 \\
30\end{array}$ & 56.67 & 43.33 \\
\hline & & & 2018 & Lady Finger & 60 & 40 & 60 \\
\hline \multirow[t]{2}{*}{2} & \multirow[t]{2}{*}{$\begin{array}{l}\text { Bariakhop- } \\
\text { SSS }\end{array}$} & \multirow[t]{2}{*}{0.50 acre } & 2017 & $\begin{array}{l}\text { Cabbage } \\
\text { Radish } \\
\text { Beans } \\
\text { Pea } \\
\text { Maize }\end{array}$ & $\begin{array}{l}15 \\
8 \\
8 \\
5 \\
15 \\
\end{array}$ & 100 & - \\
\hline & & & 2018 & $\begin{array}{l}\text { Maize } \\
\text { Radish } \\
\text { Beans } \\
\text { Pea } \\
\text { Pumpkin } \\
\text { Chilly } \\
\end{array}$ & $\begin{array}{l}15 \\
10 \\
11 \\
8 \\
5 \\
2 \\
\end{array}$ & 100 & - \\
\hline \multirow[t]{2}{*}{3} & \multirow{2}{*}{$\begin{array}{l}\text { Lingchom } \\
\text { SSS }\end{array}$} & \multirow[t]{2}{*}{0.30 acre } & 2017 & Vegetables & 10 & 100 & - \\
\hline & & & 2018 & Vegetables & 15 & 100 & - \\
\hline 4 & $\begin{array}{l}\text { Pelling - SSS } \\
100\end{array}$ & 1.5 acres & 2017 & $\begin{array}{l}\text { Potato } \\
\text { Peas } \\
\text { Beans } \\
\text { Radish } \\
\end{array}$ & $\begin{array}{l}400 \\
40 \\
40 \\
100 \\
\end{array}$ & $\begin{array}{l}80 \\
100 \\
100 \\
100\end{array}$ & $\begin{array}{l}20 \\
- \\
- \\
-\end{array}$ \\
\hline \multirow[t]{2}{*}{5} & \multirow[t]{2}{*}{ Yuksam - SSS } & \multirow[t]{2}{*}{0.6 acres } & 2017 & $\begin{array}{l}\text { Cardamom } \\
\text { Radish }\end{array}$ & $\begin{array}{l}12 \\
4.5\end{array}$ & $-\overline{-}$ & $\begin{array}{l}100 \\
-\end{array}$ \\
\hline & & & 2018 & $\begin{array}{l}\text { Tomato } \\
\text { Cauliflower } \\
\text { Broccoli } \\
\text { Chilly } \\
\text { Cardamom } \\
\end{array}$ & $\begin{array}{l}45 \\
10 \\
12 \\
3 \\
20 \\
\end{array}$ & $\begin{array}{l}95 \\
100 \\
100 \\
90 \\
- \\
\end{array}$ & $\begin{array}{l}5 \\
10 \\
100 \\
- \\
\end{array}$ \\
\hline \multirow[t]{2}{*}{6} & \multirow[t]{2}{*}{ Sopakha - SS } & \multirow[t]{2}{*}{0.25 acres } & 2017 & Soybean & 5 & 100 & - \\
\hline & & & 2018 & Pea, Soybean & 4 & 100 & - \\
\hline \multirow[t]{2}{*}{7} & \multirow[t]{2}{*}{$\begin{array}{l}\text { Hee } \\
\text { Yangthang } \\
\text { S S }\end{array}$} & \multirow[t]{2}{*}{1 acre } & 2017 & $\begin{array}{l}\text { Cabbage } \\
\text { Cauliflower } \\
\text { Beans } \\
\text { Radish } \\
\text { Chilli } \\
\text { Brinjal } \\
\text { Tomatoes }\end{array}$ & $\begin{array}{l}30 \\
30 \\
21 \\
12 \\
5 \\
10 \\
8 \\
\end{array}$ & $\begin{array}{l}70 \\
70 \\
100 \\
50 \\
100 \\
50 \\
70 \\
\end{array}$ & $\begin{array}{l}30 \\
30 \\
50 \\
50 \\
30 \\
50 \\
70 \\
\end{array}$ \\
\hline & & & 2018 & $\begin{array}{l}\text { Cabbage } \\
\text { Cauliflower } \\
\text { Beans } \\
\text { Radish } \\
\text { Potatoes } \\
\text { Cardamom }\end{array}$ & $\begin{array}{l}15 \\
20 \\
10 \\
8 \\
12 \\
10\end{array}$ & $\begin{array}{l}70 \\
70 \\
70 \\
100 \\
60 \\
100\end{array}$ & $\begin{array}{l}30 \\
30 \\
30 \\
- \\
40 \\
-\end{array}$ \\
\hline
\end{tabular}

Source: Field Survey, October, 2018. 
Table 2: Year wise Organic Products in the schools of South district

\begin{tabular}{|c|c|c|c|c|c|c|c|}
\hline $\begin{array}{l}\text { Sl. } \\
\text { No }\end{array}$ & $\begin{array}{l}\text { Name of } \\
\text { School }\end{array}$ & $\begin{array}{lr}\begin{array}{l}\text { Area of } \\
\text { used }\end{array} & \text { fand } \\
\text { Farming } \\
\text { (approx }\end{array}$ & Year & $\begin{array}{l}\text { Name of the } \\
\text { crops } \\
\text { Vegetables } \\
\text { grown }\end{array}$ & $\begin{array}{l}\text { Production } \\
\text { (in Kg.) }\end{array}$ & $\begin{array}{l}\text { Produce } \\
\text { used } \\
\text { in MDM } \\
(\%)\end{array}$ & $\begin{array}{l}\text { Produce } \\
\text { Sold }(\%)\end{array}$ \\
\hline \multirow[t]{2}{*}{1} & \multirow{2}{*}{$\begin{array}{l}\text { Bermiok- } \\
\text { Tokal - SSS }\end{array}$} & \multirow[t]{2}{*}{0.0160 acres } & 2017 & Vegetables & 40 & 100 & - \\
\hline & & & 2018 & Vegetables & 40 & 100 & - \\
\hline 2 & $\begin{array}{l}\text { Namchi } \\
\text { Girls SSS }\end{array}$ & 0.0045 acres & 2018 & $\begin{array}{l}\text { Coriander } \\
\text { Beans } \\
\text { Radish }\end{array}$ & $\begin{array}{l}6 \\
14 \\
9 \\
\end{array}$ & $\begin{array}{l}100 \\
71 \\
-\end{array}$ & $\begin{array}{l}- \\
29 \\
100\end{array}$ \\
\hline \multirow[t]{2}{*}{3} & \multirow[t]{2}{*}{$\begin{array}{l}\text { Sadam } \\
\text { SSS }\end{array}$} & \multirow[t]{2}{*}{0.0272 acres } & 2017 & $\begin{array}{l}\text { Beans } \\
\text { Pea }\end{array}$ & $\begin{array}{l}5 \\
2 \\
\end{array}$ & $\begin{array}{l}100 \\
100 \\
\end{array}$ & - \\
\hline & & & 2018 & $\begin{array}{l}\text { Beans } \\
\text { Spinach }\end{array}$ & $\begin{array}{l}8 \\
8 \\
\end{array}$ & $\begin{array}{l}100 \\
100\end{array}$ & - \\
\hline \multirow[t]{2}{*}{4} & \multirow[t]{2}{*}{$\begin{array}{l}\text { Yangang - } \\
\text { SSS }\end{array}$} & \multirow[t]{2}{*}{0.04592 acres } & $\begin{array}{l}2- \\
017\end{array}$ & $\begin{array}{l}\text { Beans } \\
\text { Radish } \\
\text { Potato }\end{array}$ & $\begin{array}{l}10 \\
10 \\
10\end{array}$ & $\begin{array}{l}100 \\
100 \\
100\end{array}$ & $\begin{array}{l}- \\
- \\
-\end{array}$ \\
\hline & & & 2018 & $\begin{array}{l}\text { Chilly } \\
\text { Squash } \\
\text { Beans } \\
\end{array}$ & $\begin{array}{l}30 \\
30 \\
30 \\
\end{array}$ & $\begin{array}{l}100 \\
100 \\
100\end{array}$ & \\
\hline
\end{tabular}

Source: Field Survey, October, 2018.

Table 3: Year wise Organic Products in the schools of North district

\begin{tabular}{|c|c|c|c|c|c|c|c|}
\hline $\begin{array}{l}\text { Sl. } \\
\text { No }\end{array}$ & \begin{tabular}{|ll} 
Name & of \\
School
\end{tabular} & $\begin{array}{l}\text { Area of } \\
\text { Land used } \\
\text { for Farming } \\
\text { (approx in } \\
\text { acres) }\end{array}$ & Year & $\begin{array}{l}\text { Name of the } \\
\text { crops } \\
\text { Vegetables } \\
\text { grown }\end{array}$ & $\begin{array}{l}\text { Production } \\
\text { (in Kg.) }\end{array}$ & $\begin{array}{l}\text { Produce } \\
\text { used } \\
\text { in MDM } \\
(\%)\end{array}$ & $\begin{array}{l}\text { Produce } \\
\text { Sold }(\%)\end{array}$ \\
\hline \multirow[t]{2}{*}{1} & \multirow[t]{2}{*}{ Phodong - SSS } & \multirow[t]{2}{*}{0.0045 acres } & 2017 & $\begin{array}{l}\text { Beans } \\
\text { Spinach }\end{array}$ & $\begin{array}{l}7 \\
5\end{array}$ & $\begin{array}{l}100 \\
100\end{array}$ & - \\
\hline & & & 2018 & $\begin{array}{l}\text { Beans } \\
\text { Bitter-gourd } \\
\text { Chilly } \\
\end{array}$ & $\begin{array}{l}7 \\
5 \\
5 \\
\end{array}$ & $\begin{array}{l}100 \\
100 \\
100 \\
\end{array}$ & $\begin{array}{l}- \\
- \\
-\end{array}$ \\
\hline \multirow[t]{2}{*}{2} & \multirow[t]{2}{*}{$\begin{array}{l}\text { Eklavya Model } \\
\text { Residential } \\
\text { School }\end{array}$} & \multirow[t]{2}{*}{1 acre } & 2017 & $\begin{array}{l}\text { Spinach } \\
\text { Potato } \\
\text { Radish } \\
\text { Beans } \\
\text { Cherry pepper }\end{array}$ & $\begin{array}{l}10 \\
20 \\
5 \\
15 \\
1 \\
\end{array}$ & $\begin{array}{l}100 \\
- \\
- \\
-\end{array}$ & $\begin{array}{l}- \\
100 \\
100 \\
100 \\
100\end{array}$ \\
\hline & & & 2018 & $\begin{array}{l}\text { Peas } \\
\text { Coriander } \\
\text { Radish } \\
\end{array}$ & $\begin{array}{l}2 \\
10 \\
3 \\
\end{array}$ & $\begin{array}{l}100 \\
100 \\
100 \\
\end{array}$ & $\begin{array}{l}- \\
-\end{array}$ \\
\hline 3 & Lingthem - JHS & 0.5 acres & 2018 & $\begin{array}{l}\text { Squash } \\
\text { Beans } \\
\text { Cardamom } \\
\end{array}$ & $\begin{array}{l}10 \\
6 \\
6 \\
\end{array}$ & $\begin{array}{l}100 \\
100 \\
-\quad \\
\end{array}$ & 100 \\
\hline \multirow[t]{2}{*}{4} & \multirow{2}{*}{$\begin{array}{l}\text { Sonamchoda } \\
\text { Lepcha } \\
\text { Memorial - SSS }\end{array}$} & \multirow[t]{2}{*}{1 acres } & 2017 & Tomato & 300 & 50 & 50 \\
\hline & & & 2018 & Tomato & 80 & 50 & 50 \\
\hline
\end{tabular}

Source: Field Survey, October, 2018. 
Table 4: Year wise Organic Products in the schools of East district

\begin{tabular}{|c|c|c|c|c|c|c|c|}
\hline $\begin{array}{l}\text { Sl. } \\
\text { No }\end{array}$ & $\begin{array}{l}\text { Name of } \\
\text { School }\end{array}$ & $\begin{array}{l}\begin{array}{l}\text { Area of } \\
\text { used }\end{array} \\
\text { Fand } \\
\text { (appror } \\
\text { acres) } \\
\text { acring }\end{array}$ & Year & $\begin{array}{l}\text { Name of the } \\
\text { crops } \\
\text { Vegetables } \\
\text { grown }\end{array}$ & $\begin{array}{l}\text { Production } \\
\text { (in Kg.) }\end{array}$ & $\begin{array}{l}\text { Produce } \\
\text { used } \\
\text { in MDM } \\
(\%)\end{array}$ & $\begin{array}{l}\text { Produce } \\
\text { Sold }(\%)\end{array}$ \\
\hline \multirow[t]{2}{*}{1} & \multirow{2}{*}{$\begin{array}{l}\text { Khamdong } \\
\text { SS }\end{array}$} & \multirow[t]{2}{*}{0.0688 acres } & 2017 & Vegetables & 40 & 100 & - \\
\hline & & & 2018 & Vegetables & 45 & 100 & - \\
\hline \multirow[t]{2}{*}{2} & \multirow[t]{2}{*}{ Tumin - SS } & \multirow[t]{2}{*}{1 acre } & 2017 & $\begin{array}{l}\text { Maize } \\
\text { Soya-bean }\end{array}$ & $\begin{array}{l}15 \\
7\end{array}$ & $\begin{array}{l}100 \\
-\end{array}$ & $\begin{array}{l}- \\
100\end{array}$ \\
\hline & & & 2018 & Vegetables & 20 & 50 & 50 \\
\hline \multirow[t]{2}{*}{3} & \multirow[t]{2}{*}{ Sichey - SS } & \multirow[t]{2}{*}{0.120 acres } & 2017 & $\begin{array}{l}\text { Beans } \\
\text { Radish }\end{array}$ & $\begin{array}{l}10 \\
12 \\
\end{array}$ & $\begin{array}{l}100 \\
100 \\
\end{array}$ & - \\
\hline & & & 2018 & Pumpkin & 18 & 100 & - \\
\hline \multirow[t]{3}{*}{4} & $\begin{array}{l}\text { Enchey } \\
\text { SSS }\end{array}$ & 0.25 acres & 2017 & $\begin{array}{l}\text { Radish } \\
\text { Potato }\end{array}$ & $\begin{array}{l}15 \\
15\end{array}$ & $\begin{array}{l}5 \\
5\end{array}$ & $\begin{array}{l}95 \\
95\end{array}$ \\
\hline & \multirow[t]{2}{*}{$\begin{array}{l}\text { Penlong } \\
\text { SS }\end{array}$} & \multirow[t]{2}{*}{0.0367 acres } & 2017 & $\begin{array}{l}\text { Squash } \\
\text { Beans }\end{array}$ & $\begin{array}{l}20 \\
20\end{array}$ & $\begin{array}{l}100 \\
100\end{array}$ & - \\
\hline & & & 2018 & $\begin{array}{l}\text { Radish } \\
\text { Potato }\end{array}$ & $\begin{array}{l}5 \\
10 \\
\end{array}$ & $\begin{array}{l}100 \\
100\end{array}$ & $\begin{array}{l}- \\
-\end{array}$ \\
\hline
\end{tabular}

Source: Field Survey, October, 2018.

The study highlights that there is an involvement of teachers, students and various agencies in the process of organic farming in the schools. Other than Human Resource Development Department, the Department of Horticulture \& Agriculture- Govt. of Sikkim and Spice Board - Govt. of Sikkim were directly engaged in the process. These agencies supported the schools with the training and workshops, orientations on organic farming and other essentials items required for farming like; seeds, saplings, water tanks, farming tools and greenhouse shed. Local community members like farmers, Self Help Groups and SMC Members have been extending their support in the form of manual labour in the preparation of farming beds, assisting the schools in other necessary tasks etc. This involvement of all the stakeholders and community in the process is reflective of the collaborative approaches in the activities which encompass the ESD components of participative learning with social responsibility.

The following figures below elicits the direct involvement of students, teachers, community and other stake holders in the process of organic farming activity in schools. 


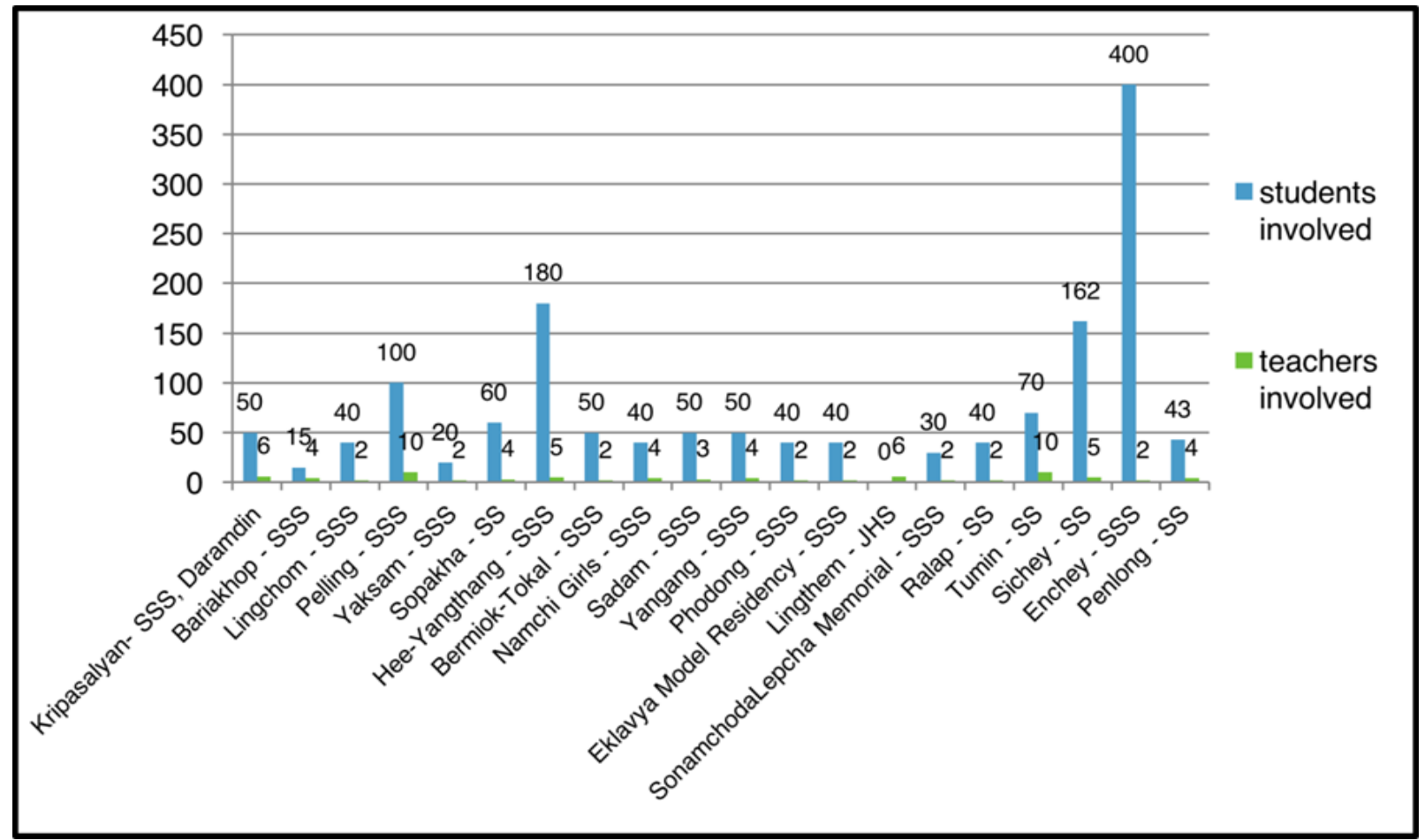

Figure 1: Number of teachers and students engaged in organic farming in selected schools Source: Field Survey, October, 2018.

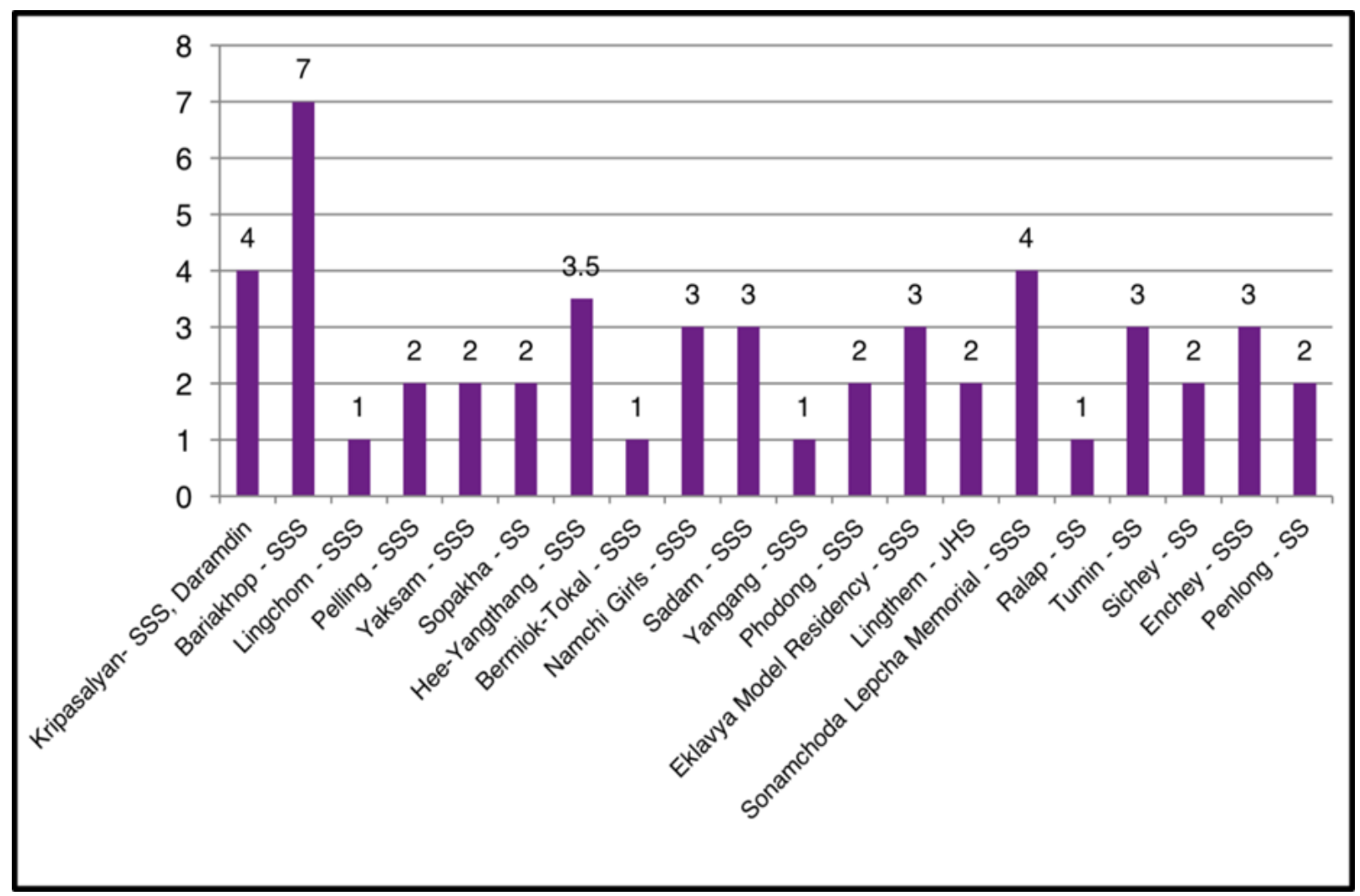

Figure 2: Time spent (in hours) in farming activity per week Source: Field Survey, October, 2018. 


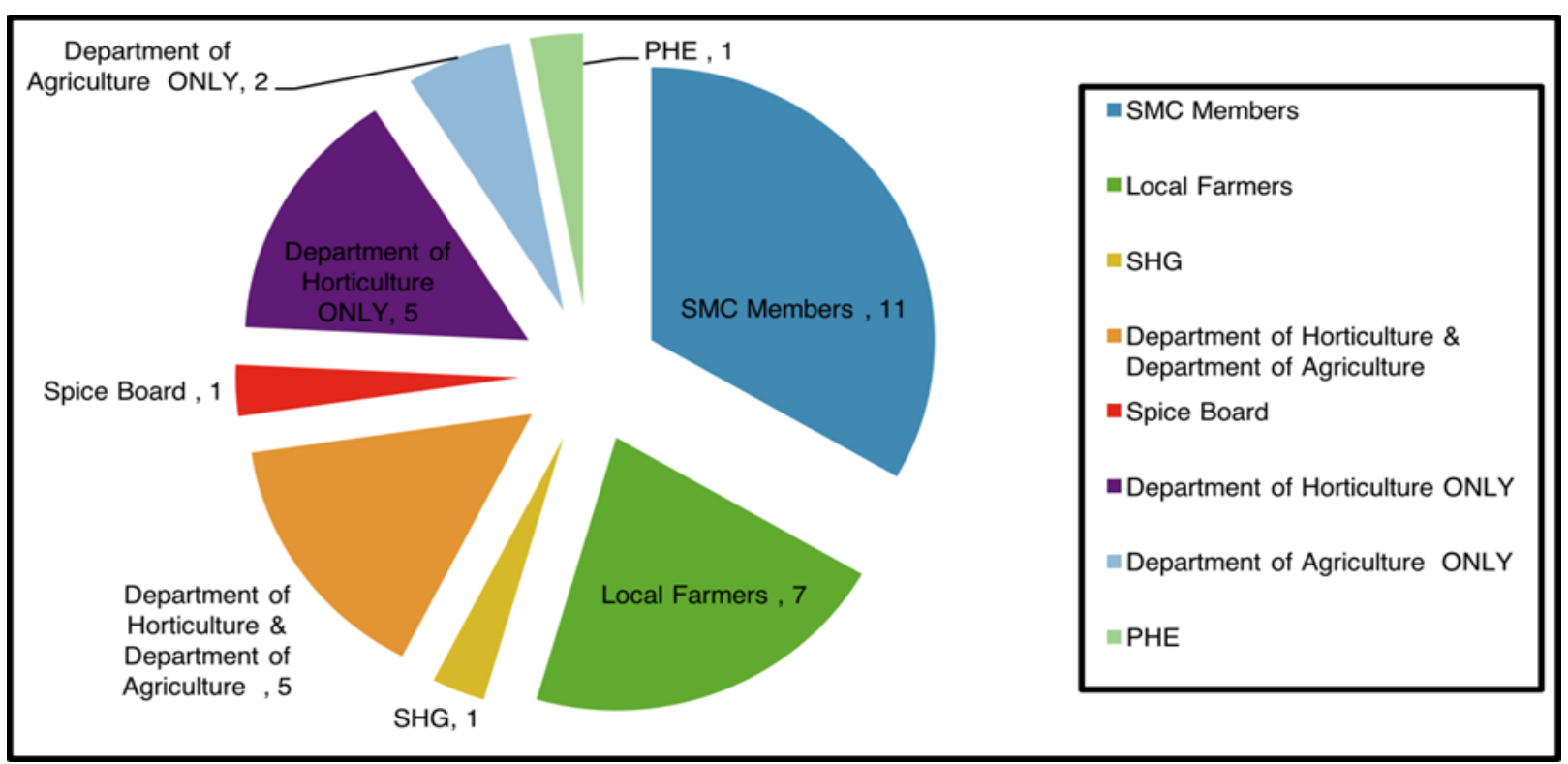

Figure 3: Agencies involved in organic farming in schools

Source: Field Survey, October, 2018.

Adding on to the present study on integration of organic farming in government schools in Sikkim, development of school curriculum for vocational education to align the practice of Organic Farming under the vocational subject of Organic Agriculture has also taken shape.

In continuation to the initiative of institutionalizing Organic Farming, HRDD has also proposed the development of curriculum for classes IX and X on Organic Farming as a new Vocational Trade to be introduced in government schools. In this regard, a working group under the guidance of SCERT Sikkim has initiated preliminary work with PSS Central Institute of Vocational Education, Bhopal (NCERT, MHRD) to work on designing curriculum on 'Organic Agriculture'. The subject will be taught at the secondary level of government schools of Sikkim under Vocational Course.

With this, Organic farming which is based on the principles of Health; Ecology; Fairness and Care will inevitably contribute to the objective of ESD which in turn aims to reorient education towards the meeting of sustainable development goals. In addition, the inclusion of Organic farming in the curriculum will also help facilitate a 'closer integration of learning and work' for all Sikkimese learners in their local environment.

\section{Conclusion}

The above study is an indicative of the Sikkim schools being inclusive of Education for sustainable development with the role of the schools, community and the governing bodies together working towards the objective of transforming education to shape a more sustainable world. The study reflects on the experiential education where students of all ages enjoy active learning and connectedness with practice. The incorporation and practice of organic farming/agriculture at school level allows spurting motivated learners. There is a total chance to apply the learning's in action leading to sustainable living. The idea of student-based organic farming education is not 
just about teaching organic, ecological, or sustainable farming principles, rather it is more about connecting people of all fields and ages to work together. The education shift to organic agriculture for sustainable development develops an understanding of interconnectedness which experiences the principles of common ownership of living together for sustainability.

\section{References}

[1] Ahlem, Zouari \& Hammas, M.A. Organic Farming: A Path to Sustainable Development, Department of Economics, FSEGS, University of Sousse, Tunisia, 2014.

[2] Biernbaum, J. A. Student and New Farmer Education to Support the Growth of Organic Farming, Department of Horticulture, Michigan State University, East Lansing, 2006, MI 48824.

[3] Lotter, Donald W., 2008. Organic Agriculture, The Rodale Institute, 611 Siegfriedale Road, Kutztown.

[4] National Council of Educational Research and Training (NCERT). National Curriculum Framework. NCERT. New Delhi, 2005.

[5] National Council of Educational Research and Training (NCERT). Organic Farming for Class VIVIII. NCERT, New Delhi, 2018.

[6] Sachs J. The age of sustainable Development, New York, Columbia University, 2015.

[7] Sharma. K, Pandya. M. Towards a Green School on Education for Sustainable Development for Elementary Schools, National Council of Educational Research and Training (NCERT), New Delhi, 2015.

[8] UNESCO, Mahatma Gandhi Institute of Education for Peace and Sustainable Development (MGIEP). Text Book for sustainable development - A Guide to embedding, New Delhi, 2017.

\footnotetext{
*Corresponding author.

E-mail address: syangbog@gmail.com
} 